\title{
Optimization of Coconut Water Beverage Fermented with Lactobacillus acidophilus
}

\author{
Eileen B. Bandalan and Lorina A. Galvez \\ Department of Food Science \& Technology, Visayas State University \\ Visca, Baybay City Leyte, 6521-A Philippines
}

\begin{abstract}
Coconut water is the liquid endosperm of coconut. It is a very nutritious and refreshingly natural beverage but highly perishable. The study aimed to optimize and evaluate the coconut water beverage formulation. A $3^{3}$ factorial experiment arranged in Central Composite Design with the levels of Lactobacillus acidophilus starter culture $(10,15,20 \%)$, pineapple puree as flavorant $(5,15,25 \%)$ and sugar $(10,20,30 \%)$ as the independent variables was used. The growth pattern of the lactic acid bacteria was monitored for 32 hours following serial dilution and pour plating techniques to determine the fermentation time to produce the beverage. Sensory evaluation was conducted using the 9-point Hedonic scale. Response surface methodology was used to identify the optimum formulation. Microbial growth indicated that 24 hours of incubation at $37^{\circ} \mathrm{C}$ can produce the fermented beverage. With increased level of Lactobacillus acidophilus starter culture, pineapple puree and sugar, acceptability for the product increased. The optimum formulation has 30\% sugar, $20 \%$ starter culture, and 15\% pineapple puree. The product is more nutritious than the unfermented beverage and still acceptable when stored at refrigerated condition for 15 days. Fermentation increased the nutritional values of fresh coconut water.
\end{abstract}

Keywords: coconut water, fermentation, preservation, sensory evaluation, development

\section{INTRODUCTION}

Coconut water is the liquid endosperm filling the central cavity of coconuts. It is considered as one of the world's most versatile natural products because of its various applications in different areas especially tissue culture, food industry, and medicine. The major challenge faced by coconut water manufacturers is the extension of the product's shelf-life as well as the preservation of the characteristic and the distribution of the product to non-coconut producing regions. Coconut water by nature contains oxidative enzymes making it highly perishable. The water inside the fruit is sterile but when it is extracted and exposed to air, it immediately undergoes oxidation in addition to microbial contamination which may occur when extraction is done carelessly, resulting to the loss or decrease of its quality. The use of adequate processes for the preservation of coconut water will extend the shelf life and consequently optimize its use. It will also contribute to the

Correspondence: E.B. Bandalan Address: Department of Food Science \& Technology, Visayas State University, Visca, Baybay City Leyte, 6521-A Philippines Tel.: +639066531844 E-mail: everland_ayen@yahoo.com 
generation of jobs and additional income for the coconut farmers.

The preservation of food by fermentation is one of the oldest methods known to mankind. Fermentation is a process which brings about chemical changes in protein, carbohydrates or fat components of any product through the action of enzymes released by specific microorganisms. A microorganism which is used for the preparation of fermented product is known as starter. Lactic acid bacteria (LAB) are often used for the production of various fermented milk products, hence are called dairy starter cultures. The usual practice to manufacture the lactic beverage is to add conventional yogurt bacteria such as Lactobacillus bulgaricus and Streptococcus thermophilus as well as probiotic bacteria like Lactobacillus acidophilus to enhance the fermentation process (Yuliana et al., 2010). Other nondairy substrates can also be used in the production of fermented beverage with LAB starter cultures like coconut water and fruit juices.

Fermentation of the coconut water will make the product a healthier drink, extend its shelf life and will make it stable during storage and distribution. However, the nutrients present in the coconut water are not enough for the starter culture to start the fermentation process. The addition of skim milk powder, sucrose, as well as flavor will not only provide the necessary nutrients for the starter culture to start the fermentation but will also enhance the taste and general acceptability of the product. This study was conducted to optimize the formulation of fermented coconut water beverage.

\section{MATERIALAND METHODS}

\section{Preparation of Starter Cultures}

Starter cultures were prepared following the methods used by Gandhi (2006). Skim milk powder $(12 \% \mathrm{w} / \mathrm{v})$ used in the culture preparation was reconstituted with $88 \%$ distilled water and was autoclaved at 10 psi for $10-15$ minutes. The pasteurized milk was cooled to $35-40^{\circ} \mathrm{C}$ before the activated pure culture of Lactobacillus acidophilus 1900 was inoculated at the rate of $2 \%$ per liter. The inoculated milk was then incubated at $37 \pm 1^{\circ} \mathrm{C}$ for 24 hours. After incubation, the prepared starter culture was cooled to $5^{\circ} \mathrm{C}$ if it was used after more than 6 hours and at $10-12^{\circ} \mathrm{C}$ if it was used within 6 hours.

\section{Product Preparation}

Coconut water was aseptically collected and filtered several times to remove any suspended dirt. It was subjected to heat treatment for $10-15$ minutes at $90^{\circ} \mathrm{C}$ to destroy pathogenic and other heat-sensitive microorganisms. Refined sugar was added at different levels while the coconut water was still hot to facilitate the mixing process. Skimmed milk powder was added to the pasteurized coconut water at $6 \%$ (w/v) while the water was still slightly hot. Pineapple puree as flavorant was added immediately after the sugar and the skim milk powder was completely dissolved. The beverage was cooled in an ice bath until the desired growth temperature (35$40^{\circ} \mathrm{C}$ ) for the $(\mathrm{LAB})$ was attained. Prepared starter culture was added at different levels and inoculated beverage was allowed to ferment at $37-40^{\circ} \mathrm{C}$ for $24-32$ hours. 
ExperimentalDesign

In order to optimize the product formulation, a Central Composite Design was employed with 15 treatments as experimental combinations (Figure 1).

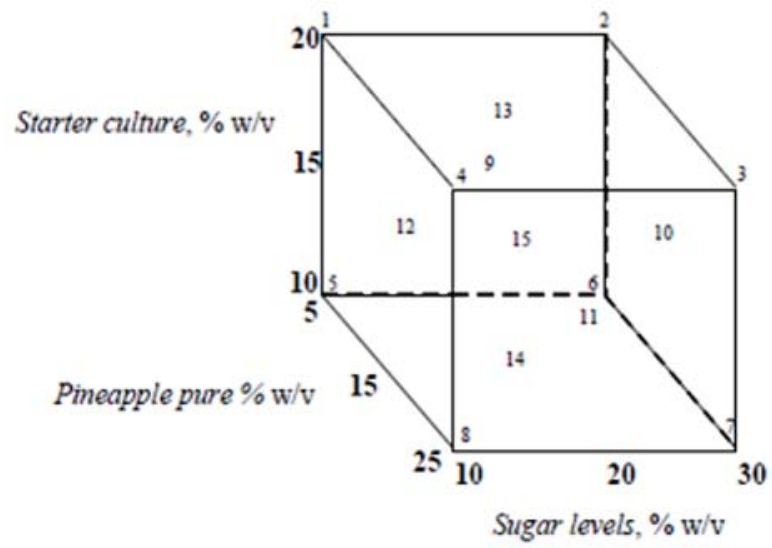

Figure 1. A Central Composite Design for Fermented Coconut water Beverage Production.

\section{Sensory Evaluation}

Thirty five (35) Food Technology students of the Visayas State University, Visca, Baybay City, Leyte evaluated the fermented beverage. Presentation of samples was carried out following the Incomplete Block design set plan 13.7 as laid out by Cochran and Cox (1957).

Physic-chemical Analysis

The Total Soluble Solids (TSS) and $\mathrm{pH}$ and \% TA were analyzed following AOAC (1980). Percent lactic acid was calculated following the formula:

$\%$ Lactic Acid $=\frac{(\text { vol. of } \mathrm{NaOH})(\mathrm{N} \text { of } \mathrm{NaOH})(0.009)(100)}{\text { Volume of the sample }}$

Statistical Analysis and Formulation Optimization

The data obtained from the sensory evaluation of the different treatments were subjected to Response surface regression analysis to determine the effects of the independent variables on the sensory qualities of the product. The optimum levels were determined by collectively considering all sensory attributes in one graph and evaluate them as one.

\section{Determination of Optimum Fermentation Time}

Microbial counts were monitored for 32 hours at 4-hour interval to determine optimum fermentation time for the product. Serial dilution and pour plating 
techniques using de Man Rosa Agar (MRS agar) was used to carry out the activity. Viable colonies were counted and total microbial count (Standard plate count) was expressed as $\mathrm{CFU} / \mathrm{ml}$.

\section{Nutritional Content Determination}

A sample of the formulated product prepared at optimum conditions was sent to the F.A.S.T Laboratory in Mandaue City, Cebu Philippines for the proximate analysis (Total fat, total sugar, total protein and ash) for labeling and nutritional claim purposes.

\section{RESULTS AND DISCUSSION}

The acceptability of the fermented beverage was generally enhanced by the addition of starter cultures and sugar (Table 1). Levels of pineapple puree on the other hand, did not significantly affect the general acceptability of the beverage.

The rancid-like aftertaste of coconut water collected from not freshly harvested coconuts was offset by the addition of pineapple puree as flavorant and through the process of fermentation with the use of LAB as starter culture.

The shaded regions in Figure 2 showed the possible optimum regions that satisfy the required sensory acceptability rating and cost of the product.

Any combination found inside the shaded optimum region can be used in producing the fermented coco beverage. To control the consistency of the quality of the beverage, one (1) point should be used for processing purposes and the combination points found inside the shaded region could be used as reference or critical limits should problems occur during production like deviations from the quality standard. For processing and quality control purposes, the combination of starter culture, pineapple puree and sugar levels was set at 20,15, and $30 \% \mathrm{w} / \mathrm{v}$, respectively.

Table 1. Parameter estimates of the response for the sensory acceptability of the fermented beverage.

\begin{tabular}{lcccccc}
\hline \multicolumn{1}{c}{ Parameter } & Color & Aroma & Flavor & Taste & Aftertaste & $\begin{array}{c}\text { General } \\
\text { Acceptability }\end{array}$ \\
\hline Intercept & $6.57^{* *}$ & $6.28^{* *}$ & $6.37^{* *}$ & $6.52^{* *}$ & $6.44^{* *}$ & $7.56^{* *}$ \\
SC & $-2.23^{*}$ & $-0.45^{\mathrm{ns}}$ & $-1.10^{\mathrm{ns}}$ & $-1.29^{\mathrm{ns}}$ & $-1.22^{\mathrm{ns}}$ & $-1.97^{*}$ \\
PP & $3.31^{* *}$ & $0.67^{\mathrm{ns}}$ & $0.38^{\mathrm{ns}}$ & $0.25^{\mathrm{ns}}$ & $-0.24^{\mathrm{ns}}$ & $0.40^{\mathrm{ns}}$ \\
Suger & $-0.45^{\mathrm{ns}}$ & $-2.50^{*}$ & $-2.20^{*}$ & $-2.34^{*}$ & $-2.30^{*}$ & $-2.95^{* *}$ \\
SC*SC & $2.13^{*}$ & $0.08^{\mathrm{ns}}$ & $1.01^{\mathrm{ns}}$ & $0.92^{\mathrm{ns}}$ & $0.91^{\mathrm{ns}}$ & $1.53^{\mathrm{ns}}$ \\
PP*SC & $-0.42^{\mathrm{ns}}$ & $0.00^{\mathrm{ns}}$ & $1.27^{\mathrm{ns}}$ & $1.19^{\mathrm{ns}}$ & $0.71^{\mathrm{ns}}$ & $1.11^{\mathrm{ns}}$ \\
PP*PP & $-2.53^{*}$ & $0.30^{\mathrm{ns}}$ & $-0.98^{\mathrm{ns}}$ & $-0.66^{\mathrm{ns}}$ & $0.09^{\mathrm{ns}}$ & $-0.85^{\mathrm{ns}}$ \\
Sugar*SC & $0.57^{\mathrm{ns}}$ & $2.77^{* *}$ & $1.14^{\mathrm{ns}}$ & $2.30^{*}$ & $2.21^{*}$ & $2.97^{* *}$ \\
Sugar*PP & $-1.34^{\mathrm{ns}}$ & $-1.79^{\mathrm{ns}}$ & $-0.95^{\mathrm{ns}}$ & $-0.96^{\mathrm{ns}}$ & $-1.15^{\mathrm{ns}}$ & $-1.19^{\mathrm{ns}}$ \\
Sugar*Sugar & $0.45^{\mathrm{ns}}$ & $2.08^{*}$ & $2.46^{*}$ & $2.23^{*}$ & $2.13^{*}$ & $2.59^{* *}$ \\
\hline
\end{tabular}

$\mathrm{SC}=$ starter culture $\mathrm{PP}=$ pineapple Puree $*=$ significant at $5 \% * *=$ significant at $1 \% \mathrm{~ns}=$ not significant

Figure 3 illustrates the microbial growth curve of Lactobacillus acidophilus bacteria on the coconut water beverage during fermentation. The figure shows that the growth of Lactobacillus acidophilus in the beverage followed a specific pattern (Ebing \& Rutgers, 2006) that is typical for lactic acid bacteria. 
The adaptation of the bacteria in its new environment was quite long that it lasted for 12 hours. The rapid rise of the microbial cells in the product signaled the start of the multiplication of the bacterial cells. At this stage, lactic acid was produced almost exclusively considering that the Lactobacillus acidophilus is a homofermentative bacterium as mentioned by Gandhi (2006). After 20 hours of incubation, the growth of the bacterial cells was at maximum. This point of fermentation could be the stationary point of the bacterial growth wherein the product becomes acidic due to the production of lactic acid that limits further increase of the microbial cell count. After 24 hrs of incubation, the bacterial count started to decline. Results implied that 24 hours of incubation is sufficient for the production of fermented coconut water beverage.

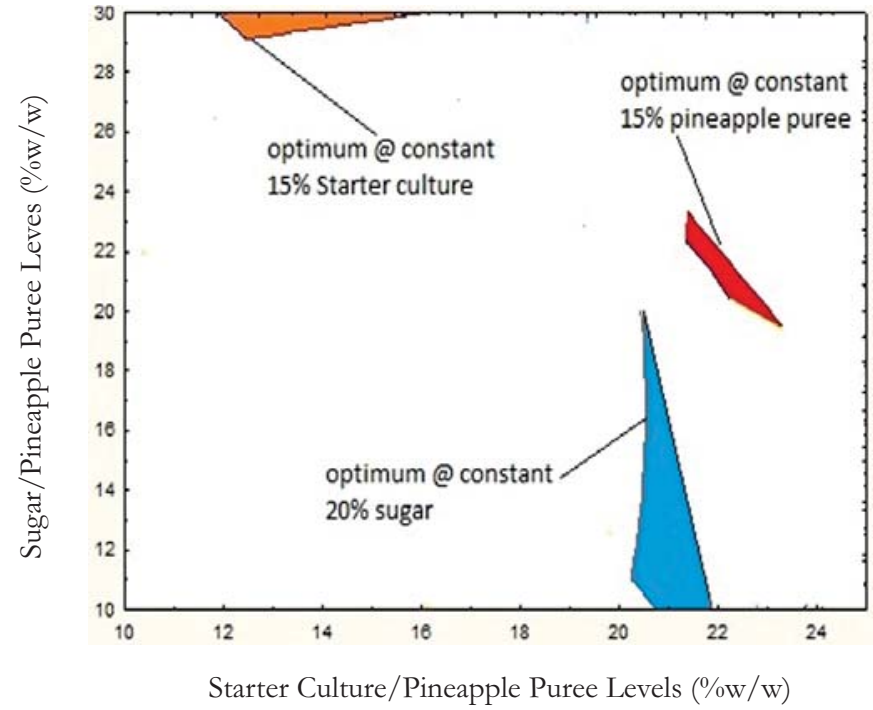

Figure 2. Superimposed Contour Plots Showing the Optimum Regions.

Analysis of Variance and T-test analysis of the product during cold storage (Table 2) showed that the fermented coco beverage produced at optimum condition has a shelf-life of $>10<15$ days. At 20 days of cold storage, $\% \mathrm{TA}$ increased and $\mathrm{pH}$ of the beverage decreased.

Table 2. Microbial and physic-chemical properties of the product during storage.

\begin{tabular}{ccccc}
\hline Time (day) & $\begin{array}{c}\text { Mean microbial } \\
\text { count }\end{array}$ & $\mathrm{pH}$ & TSS & $\% \mathrm{TA}^{1}$ \\
\hline $5^{\text {th }}$ & $2.07 \mathrm{E}+06^{\mathrm{A}}$ & $3.9^{\mathrm{C}}$ & $26.6^{\mathrm{B}}$ & $1.8^{\mathrm{C}}$ \\
$10^{\text {th }}$ & $1.70 \mathrm{E}+06^{\mathrm{C}}$ & $4^{\mathrm{B}}$ & $25.2^{\mathrm{C}}$ & $1.89^{\mathrm{B}}$ \\
$15^{\text {th }}$ & $1.75 \mathrm{E}+06^{\mathrm{B}}$ & $4.3^{\mathrm{A}}$ & $26.8^{\mathrm{A}}$ & $1.755^{\mathrm{D}}$ \\
$20^{\text {th }}$ & $9.20 \mathrm{E}+05^{\mathrm{D}}$ & $3.6^{\mathrm{D}}$ & $26.8^{\mathrm{A}}$ & $2.43^{\mathrm{A}}$ \\
F value & Infinity** $^{*}$ & $7.39 \mathrm{E} 16^{* *}$ & Infinity**$^{*}$ & $7.04 \mathrm{E} 16^{* *}$ \\
\hline
\end{tabular}

${ }^{1}$ Titratable acidity expressed as \% lactic acid; means in the same column with the same letter are not significantly different $(\mathrm{P}<0.05)$; ** significant at $\mathrm{P}<0.001$ 


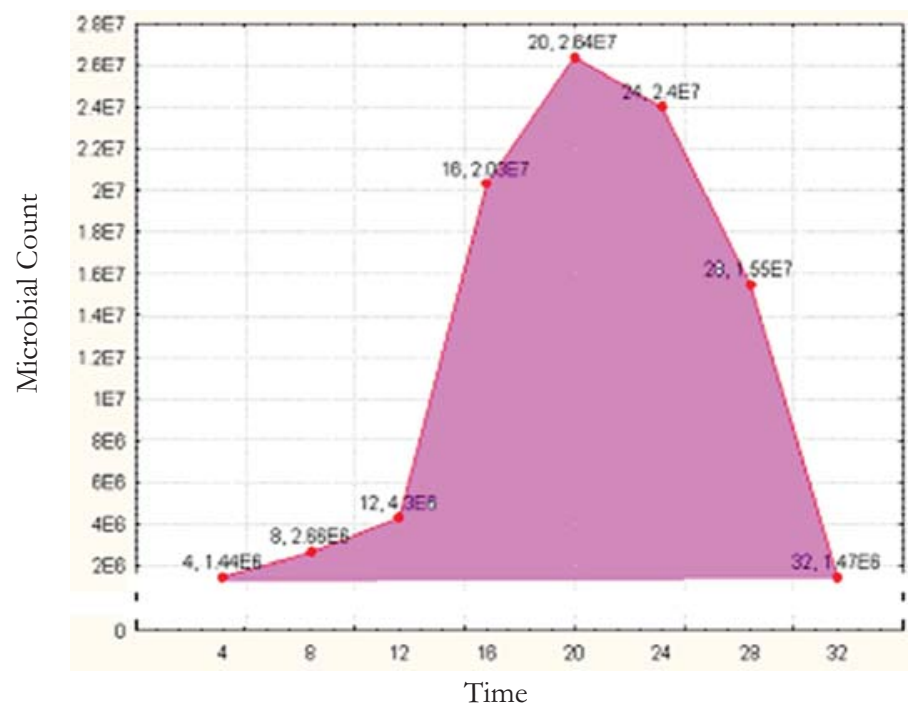

Figure 3. Mean Microbial count during Fermentation.

The nutritional values (Table 3) for the optimized formulation of fermented coconut water beverage were mostly higher as compared to its fresh and unfermented counterpart suggesting that the fermented coconut water is healthier as compared to the unfermented one. The increase in the nutritional content of the beverage could be attributed to the addition of skim, sugar, pineapple puree, and LAB starter culture.

Table 3. Proximate composition of the coco water beverage.

\begin{tabular}{ccc}
\hline Analysis & $\begin{array}{c}\text { Fresh (unfermented) coconut } \\
\text { water (Satyavati, 1987) }\end{array}$ & $\begin{array}{c}\text { Fermented Coconut water } \\
\text { beverage }\end{array}$ \\
\hline Total Fat & $0.1 \%$ & $0.1 \%$ \\
Total Protein & $0.1 \%$ & $1.2 \%$ \\
Total Sugar & $0.2 \%$ & $3.7 \%$ \\
\hline
\end{tabular}

\section{CONCLUSIONS}

Based on the results of the experiment, it was concluded that coconut water can be processed into a fermented beverage through the addition of Lactobacillus acidophilus as starter culture, sugar and pineapple puree as flavorant. The beverage produced was concluded to be acceptable and through the process of sensory evaluation, the product's formulation and fermentation condition can be optimized. The beverage with 30\% sugar, 20\% starter culture, and 15\% pineapple puree was concluded to be the optimum formulation of the product which is stable for 15 days at refrigerated condition. Fermentation therefore can be used as a method for the production and preservation of coconut water.

\section{ACKNOWLEDGEMENTS}

This study would not have been realized without the help and assistance of the following agencies and individuals: 
- DOST-ASTHRDP for the financial assistance throughout my graduate studies

- Visayas State University (VSU) and the Department of Food Science and Technology (DFST) for providing the materials and equipment needed for the experiment.

- Ms. Ma. DheliaPagente, Senior Research Specialist of the Microbiology Laboratory of the Department of Veterinary Medicine, VSU, Visca, Baybay Leyte, Philippines for the assistance, critique and pieces of advise that improved the methods and outcome of the study.

\section{REFERENCES}

AOAC.1980. Official Methods of Analysis of the Association of Official Analytical Chemists. $13^{\text {th }}$ edition. W. Horwitz (ed) Washington D.C., USA.

COCHRAN, W.G and G.N. COX. 1957. Experimental Design. $2^{\text {nd }}$ edition John Wiley and Sons, Inc. New York pp 439-482

EBING, P. and K. RUTGERS. 2006. Preparation of Dairy Products. Agrodok 36. (C) Agromisa Foundation and CTA, Wageningen, ISBN Agromisa: 90-8573062-7.ISBN CTA: 978-92-9081-341-5

GANDHI, D.N. 2006. Food and Industrial Microbiology. Microbiology of Fermented Dairy Products. National Dairy Research Institute. Karnal-132001

YULIANA, N., AZHARI RANGGA and RAKHMIATI. 2010. Manufacture of Fermented Coco Milk-drink Containing Lactic Acid Bacteria Cultures. African Journal of Food Science 4(9): 558 - 562 